\title{
Towards Developing Malaysia STEM Teacher Standard: Early Framework
}

\author{
Nurfaradilla Mohamad Nasri*, Nurfarahin Nasri, Mohamad Asyraf Abd Talib \\ Faculty of Education, Universiti Kebangsaan Malaysia, Bangi, Malaysia
}

Received April 9, 2020; Revised April 30, 2020; Accepted June 16, 2020

Copyright $\bigcirc 2020$ by authors, all rights reserved. Authors agree that this article remains permanently open access under the terms of the Creative Commons Attribution License 4.0 International License

\begin{abstract}
The quality of science, technology, engineering, and mathematics (STEM) teachers is the main determinant for achieving high quality STEM education. Therefore, in order to improve the quality of STEM education and ensure its objectives are achieved, the quality of STEM teacher should be improved. This research aims to propose an early framework of STEM Teacher Standard which could potentially serve as a guideline for STEM teachers to evaluate their competency. Delphi method (3 rounds) which involved expert panels $(n=20)$; consisting of STEM teacher educators $(n=10)$ and STEM school teachers $(n=10)$ were employed. The findings show two key dimensions essential in producing quality STEM teacher namely 'Teaching and Learning Skill' and 'Knowledge and Understanding' dimension. Interestingly, findings indicate that Teacher Professionalism dimension is the least important in producing quality STEM teacher despite being greatly emphasised by other researchers. It is argued that the exam-oriented structure of the Malaysia national education system puts an increasing demand on STEM teachers to practice effective teaching approaches to transmit the knowledge to the students. The Early Framework of the Malaysia STEM Teacher Standard could assist STEM teachers to evaluate their competencies and serve as a guide for STEM teacher educators at higher education institutions to develop a responsive and comprehensive teacher training curriculum in producing quality STEM teachers.
\end{abstract}

Keywords Quality, STEM, Delphi's Method, Teacher Standard

\section{Introduction}

Today's society is particularly focused on the quality of the teachers produced because teachers are seen as liaisons in disseminating STEM knowledge, skills and values. With that, STEM teachers are seen as the most valuable asset in the field of STEM education.

Lee [1], who analyses the development of STEM education curriculum, reported that changes in curriculum is crucial and necessary to address both local and global environmental issues. Lee's [1] opinion is supported by Kamisah et al. [2] and Darling-Hammond et al. [3] who strongly believed that changes to STEM curriculum are essential in meeting local and international demands. While various initiatives are introduced to ensure high quality STEM education, nevertheless, most developing countries including Malaysia are experiencing declination of students' interest in STEM subjects. Malaysia is taking this issue seriously by designing concerted efforts in order to raise the quality of STEM education. Despite such efforts and initiatives, students' achievement in recent Trends in International Mathematics and Science Study (TIMSS) and Program for International Student Assessment (PISA) is sadly unsatisfactory and far below international average.

Learning from the best performing countries, such as Finland, Singapore and Japan, it is clear that their strategies to improve their education system are heavily concerted on recruiting, molding and retaining high quality teachers Podolsky et al. [4]. This indicates the great importance of quality teachers in uplifting national education system. Supporting this vision, this study aims to promote quality STEM teachers by providing some standard guidelines for teachers in guiding their self-improvement strategies. Their movement is supported by Mincu [5] who strongly believed that quality teachers are the key to successful education system. Correspondingly, many researchers suggested that, the main problem in STEM education lies in the low level of competency among STEM teachers [6, 7]. The failure of STEM teachers to teach effectively is evident in a study conducted by El Nagdi et al. [8] in which STEM teachers face difficulties related to mastering specific bodies of 
STEM knowledge content thus creating professional identity conflicts as they are required to integrate and teach all four bodies of knowledge effectively. Similarly, Montgomery \& Fernández-Cárdenas [9] reported that most STEM teachers are incapable of relating disciplinary knowledge with the construction of situated solutions. From the local context, many researchers repeatedly argued that Malaysian STEM teachers have yet to perform effective teaching by encouraging active inquiry learning and meaningful learning $[10,11,12,13,14]$. As a result of ineffective STEM teaching, many students perceive STEM subjects as boring and unattractive [15].

Pertinent to this study, it is reasonable to argue that the quality of STEM teachers is one the most powerful factors that greatly influences both students' enrolment and achievement in STEM subjects. The positive relationship between the quality of teachers and the students' achievements are reported by Hess [16], Walsh [17], Zurida Hj. Ismail and Hashim Mohd. Yunus [18] and Fitzgerald et al. [19] who agreed that the effectiveness of the STEM curriculum implementation depends on STEM teachers. Acknowledging the intriguing problems related to the quality of STEM teachers, a systematic and comprehensive measure to improve their competency as quality STEM teachers should be meticulously planned.

Jamil Ahmad [20] and Siew et al. [14] reported notable differences in science achievement between students who were taught by trained and experienced science teachers and students who were taught by novice science teachers. The former group of students show higher performance in comparison to the latter group who receives teaching from novice science teachers. Although the findings from these studies only apply for science subjects, it is worth to note that similar findings might be observed in STEM subjects. In response to the Sustainable Development Goal 4 (SDG 4)- Quality Education for All, Madani [21] insisted that STEM teachers should acquire adequate capacity to become effective teachers regardless of their length of service in order to ensure quality STEM education for all students. Supporting this movement, Jamil Ahmad [20], Shernoff et al. [22] and Nagdi et al.[8] (2018) suggested that STEM teacher standard is essential in reducing the competency gap between experienced STEM teachers and less experienced STEM teachers.

Similarly, Korthagen [23] urged the need to clarify and give accurate definitions on the characteristics of quality STEM teachers. He further suggested that various complex aspects should be taken into consideration in ensuring high standard for quality of STEM teachers. Malaysia has therefore successfully developed the Malaysian Teachers Standard (MTS) for all Malaysian teachers to gauge their competency level and make self-reflection for self-improvement purposes. However, this study argues that the criteria of quality teacher set by MTS is too broad and vague particularly in assisting STEM teachers to be quality STEM teacher. Our view reflects the No Child Left Behind [24] statement in which the quality of primary and secondary school teachers, arts teachers, special education teachers and STEM teachers differs in terms of their essential characteristics and pedagogical needs. Based on this rational, it is important for these teachers to possesses different teaching skills and competency to meet diverse demands of their students.

Researchers extend this idea further by proposing that STEM teacher standard is imperative to guide teachers in their STEM teaching and learning approaches at schools [25]. Hence, the Malaysia STEM teacher standard must be developed and most importantly, should be in line with the current global demand for quality STEM teachers while recognizing the existing standards of the Malaysian Teacher Standard (MTS).

The rationale for the development of the Malaysian STEM teacher standard are multi folded to (a) serve as reference and guidance for STEM teachers to continuously improve their professionalism; (b) assist STEM teachers in self-evaluating their level of knowledge, understanding as well as teaching and learning skills and enabling them to function and act as effective STEM teachers; (c) empower agency and teachers' training institution to develop quality assurance policy for STEM teacher training curriculum; and (d) accelerate the efforts of the Ministry of Education Malaysia (MOE) to drive excellence and quality of STEM education in Malaysia.

\section{Materials and Methods}

This study employed a survey research design for data collection and utilized document analysis method and Delphi method to develop the early framework of STEM teacher standard. In general, this study consists of three phases, Phase I: draft writing and revision by checker/Raters, Phase II: Judgment by the expert panel and Phase III: Data analysis.

\subsection{Phase I}

This section discusses four core research activities involved in Phase I, namely, interviewing secondary school STEM students $(\mathrm{n}=6)$ prior to conducting Delphi method; employing document analysis method, language and grammar checking, and determining validity and reliability of the constructed dimensions.

These volunteering STEM students $(\mathrm{n}=6)$ were purposively selected involving students from national secondary school $(n=2)$, technical schools $(n=2)$ and science residential schools $(\mathrm{n}=2)$. Next, analysis of previous studies and documents related to STEM teachers' standards from other countries and Malaysian Teacher Standards (MTS) were conducted based on their relevancy and suitability to this study. Data obtained from the interview sessions and document analysis were revised, 
modified and formatted to be included in the Delphi survey questionnaire.

For Delphi survey questionnaire, three main dimensions were designed: (a) knowledge and understanding, (b) teaching and learning skills, and (c) practice of teaching professionalism value. The constructed three dimensions were primarily based on the dimensions used in the Malaysian Teacher Standards (MTS) issued by the Ministry of Education Malaysia (MOE).

The validity and reliability of the Delphi survey questionnaire were rated by a group of raters recruited in this study. The raters were categorized according to their specific roles: (i) raters who were responsible for language and grammar checking for each item in the Delphi's questionnaire survey (two postgraduate students who are competent in both Malay and English languages); and (ii) raters who were responsible in determining the reliability and validity of the items for the Delphi's questionnaire survey (two experts in STEM education). Moreover, Cohen Kappa method was taken to determine the reliability of the Delphi questionnaire. The Agreement Level of Cohen's Kappa Coefficient obtained was 0.92 which indicate high reliability of the Delphi questionnaire.

\subsection{Phase II}

In general, Phase II involves the data collection through Delphi method which invites responses from the expert. According to the International Organization for Standardization (ISO) [26] and the British Standard Institution [27], the Delphi method is a data collecting approach that is very suitable for exploring complex issues. This study utilized three rounds of Delphi method which were intended to provide an opportunity for expert panels to re-evaluate their responses from the earlier rounds. According to Linstone and Ruroff [28] and Green [29], the panel of experts must be given opportunity at least once to re-evaluate their initial responses after their responses were compared with other expert panels' responses.

The most appropriate expert panels for this study were expert individuals who were directly involved in STEM education such as STEM teacher educators $(n=10)$ and science teachers $(\mathrm{n}=10)$. The STEM teacher educators were lecturers from five research universities and the STEM teachers had at least 5 years of teaching experiences. According to Ludwig [30] and Hasson et al. [31], fifteen expert panels were sufficient for the Delphi method, thus voluntary participation from 20 expert panels were appropriate.

\subsection{Phase III}

Three analysis approaches were used for this study which were mean analysis, standard deviation analysis and quartile deviation analysis. Although these analyses were carried out separately, only items that surpassed all analysis were accepted as items for the STEM Teacher Standard.

One cut point for the mean score was set. Mean score value $\geq 4$ for an item indicated high agreement by the expert panel and therefore the item was deemed necessary (IMPORTANT) for STEM teacher. Only items with mean score value $\geq 4$ and percentage rated $\geq 90 \%$ were accepted for this study. While for standard deviation analysis, the cut point was $\mathrm{SD} \leq 0.52$. Finally, for quartile deviation analysis, a cut point was set at $\leq 0.5$ to ensure that the selected items possess high degree of agreement by the expert panel to be included for the STEM teacher standard.

\section{Results}

The results section presents findings according to the three phases involved in this study.

\section{Phase I}

Guided by the pre-determined dimensions, the data from the interview sessions and document analysis were analyzed to identify the sub dimensions as well as their individual items.

\section{Dimension A: Knowledge and Understanding}

This dimension describes the competency of knowledge and understanding that STEM teachers should master. This dimension was further divided into four sub dimensions as presented in Table 1. 
Table 1. Sub dimensions in Dimension A: knowledge and understanding

\begin{tabular}{|c|c|c|}
\hline & Sub dimensions & Number of items \\
\hline 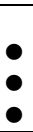 & $\begin{array}{l}\text { STEM nature } \\
\text { Know important concepts, principles, and theories in STEM } \\
\text { Know the history and advances in STEM } \\
\text { Know the philosophies and objectives in STEM }\end{array}$ & $\mathrm{n}=3$ \\
\hline ? & $\begin{array}{l}\text { Know recent advances in STEM } \\
\text { Know daily application of STEM knowledge } \\
\text { Know important issues related to STEM }\end{array}$ & $n=3$ \\
\hline $\begin{array}{l}\bullet \\
\bullet\end{array}$ & $\begin{array}{l}\text { Content of education knowledge related to STEM field } \\
\text { Know various effective approaches, methods and techniques for STEM teaching } \\
\text { Know various STEM teaching strategies such as inquiry learning, mastery learning, cooperative learning, } \\
\text { constructivist learning and contextual learning } \\
\text { Know and understand relevant STEM process skills and manipulative skills }\end{array}$ & $n=3$ \\
\hline - & $\begin{array}{l}\text { Educational resources and Information and communications technology (ICT) } \\
\text { Know various information and communication technology tools, media and educational resources to } \\
\text { support STEM teaching and learning } \\
\text { Know how to use educational technology tools }\end{array}$ & $n=2$ \\
\hline & Total & $\mathrm{N}=11$ \\
\hline
\end{tabular}

\section{Dimension B: Teaching and learning skills}

This dimension describes the competency of teaching and learning skills to be mastered by STEM teachers to ensure effective teaching process. This dimension was further divided into four sub dimensions as illustrated in Table 2.

Table 2. Sub dimensions in Dimension B: Teaching and learning skills

\begin{tabular}{|c|c|c|}
\hline & Sub dimensions & Number of items \\
\hline $\begin{array}{l}\bullet \\
\bullet \\
\bullet\end{array}$ & $\begin{array}{l}\text { Skills to develop appropriate STEM teaching and learning plan } \\
\text { Identify STEM teaching objectives according to syllabus } \\
\text { Arrange the sequence of STEM content to facilitate student understanding } \\
\text { Manage the STEM lesson content to tap into students' interest } \\
\text { Take into account students' existing knowledge when planning lessons }\end{array}$ & $\mathrm{n}=4$ \\
\hline 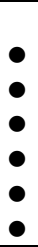 & $\begin{array}{l}\text { Skills to implement teaching and learning } \\
\text { Provide clear explanations of key concepts, principles, theories, laws and ideas in STEM } \\
\text { Skilful in handling apparatus, specimens and chemicals } \\
\text { Relate STEM knowledge with essential life skills } \\
\text { Aware of diverse students' learning needs } \\
\text { Conduct active student-centered learning } \\
\text { Instill values among students during teaching and learning process }\end{array}$ & $\mathrm{n}=6$ \\
\hline $\begin{array}{l}0 \\
\bullet \\
\bullet \\
\bullet\end{array}$ & $\begin{array}{l}\text { Skills to monitor, interpret and evaluate students' learning } \\
\text { Utilise various assessment approaches to assess student mastery } \\
\text { Provide appropriate feedback to assist students' learning } \\
\text { Analyze information from assessment to improve the teaching and students' achievement } \\
\text { Able to supervise students conducting experiments } \\
\text { Use a variety of questioning techniques to discover students' level of understanding }\end{array}$ & $\mathrm{n}=4$ \\
\hline $\begin{array}{l}\bullet \\
\bullet \\
\bullet\end{array}$ & $\begin{array}{l}\text { Classroom management skills } \\
\text { Focus on students' safety. } \\
\text { Manage students discipline in the classroom. } \\
\text { Create a conducive learning environment with accessible teaching and learning resources. }\end{array}$ & $\mathrm{n}=3$ \\
\hline & Total & $\mathrm{N}=17$ \\
\hline
\end{tabular}

\section{Dimension C: Practice of teaching professionalism value}

This dimension emphasized on the aspect of professionalism value that must be practiced by STEM teachers. This dimension consisted of three sub dimensions as presented in Table 3. 
Table 3. Sub dimensions in Dimension C: Practice of teaching professionalism value

\begin{tabular}{|c|c|}
\hline Sub dimensions & $\begin{array}{c}\text { Number of } \\
\text { items }\end{array}$ \\
\hline $\begin{array}{l}\text { Self-domain } \\
\text { Have the confidence that every student can succeed in STEM } \\
\text { Bespect every student's unique learning style } \\
\text { Be open-minded by allowing students to take charge of their own way of learning } \\
\text { - } \quad \text { Bemmitted to the learning process and intellectual development of each student } \\
\text { - }\end{array}$ & $n=5$ \\
\hline $\begin{array}{l}\text { Professional domains } \\
\text { - } \\
\text { Encourage colleagues to work collaboratively to achieve teaching and learning objectives } \\
\text { - } \quad \text { Share to attend various courses to enhance professionalism colleagues to generate innovative ideas, strategies and teaching techniques } \\
\text { - Work hard to improve the quality of science teaching and learning. }\end{array}$ & $n=4$ \\
\hline $\begin{array}{l}\text { Social domains } \\
\text { - Involve self and students in activities related to STEM } \\
\text { Establish collaborative relationships with students, colleagues and the community to support student learning } \\
\text { processes } \\
\text { Use a variety of media (printed and electronic) to communicate with various parties to improve the quality of } \\
\text { teaching and learning } \\
\text { Demonstrate high communication and social skills }\end{array}$ & $\mathrm{n}=4$ \\
\hline Total & $\mathrm{N}=13$ \\
\hline
\end{tabular}

\section{Phase II}

Phase II focuses on gathering responses from experts through Delphi Technique. Data obtain from the Delphi method was presented in Table 4.

Table 4. Responses from Experts through Delphi Technique

\begin{tabular}{|c|c|c|}
\hline & $\begin{array}{c}\text { Document analysis } \\
\text { and interview }\end{array}$ & Expert panel \\
\hline Dimension A & $\mathrm{n}=11,(26.8 \%)$ & $\mathrm{n}=9,(29.0 \%)$ \\
\hline Dimension B & $\mathrm{n}=17,(41.5 \%)$ & $\mathrm{n}=15,(48.4 \%)$ \\
\hline Dimension C & $\mathrm{n}=13,(31.7 \%)$ & $\mathrm{n}=7,(22.6 \%)$ \\
\hline Total & $\mathrm{N}=41(100 \%)$ & $\mathrm{N}=31,(100 \%)$ \\
\hline
\end{tabular}

From Table 4, it was clear that there was a stark difference between previous studies (complemented with the STEM secondary students' view) and expert panels' views in terms of the degree of emphasis for each dimension for producing quality STEM teacher. Previous studies emphasized greatly on Dimension B, followed by Dimension $\mathrm{C}$ and Dimension A. In contrast, the expert panels put more emphasis on Dimension B, Dimension A and lastly, Dimension C.

\section{Phase III}

This section reported findings from Phase III. Only items that surpassed all analysis (mean analysis, standard deviation analysis and quartile deviation analysis) were accepted as items for the STEM Teacher Standard. The number of items accepted and not accepted in this study were presented in Table 5.

Table 5. STEM Teacher Standard

\begin{tabular}{|c|c|c|c|c|}
\hline & $\begin{array}{c}\text { Number } \\
\text { of items } \\
\text { accepted }\end{array}$ & $\begin{array}{c}\text { Number } \\
\text { of items } \\
\text { not } \\
\text { accepted }\end{array}$ & Total & $\begin{array}{c}\text { Percentage } \\
\text { of items } \\
\text { accepted } \\
\text { (\%) }\end{array}$ \\
\hline $\begin{array}{c}\text { Dimension } \\
\text { A }\end{array}$ & 5 & 4 & 9 & $55.56 \%$ \\
\hline $\begin{array}{c}\text { Dimension } \\
\text { B }\end{array}$ & 11 & 4 & 15 & $73.33 \%$ \\
\hline $\begin{array}{c}\text { Dimension } \\
\text { C }\end{array}$ & 3 & 4 & 7 & $42.86 \%$ \\
\hline Total & 19 & 12 & 31 & \\
\hline
\end{tabular}

Most items from Dimension A: Knowledge and Understanding and Dimension B: Teaching and learning skills were accepted in this study. The percentage of items accepted for every dimension was calculated at $73.33 \%$ for Dimension B, followed by $55.56 \%$ for Dimension A and $42.86 \%$ for Dimension C.

\section{Proposed Early Framework of the Malaysia STEM Teacher Standard}

This study which aims to propose an early framework of STEM Teacher Standard employs 3 rounds Delphi method involving $n=10$ STEM teacher educators and $n=10$ STEM school teachers. Based on the analysis of the data gathered, this study proposed the early framework of the Malaysia STEM teacher standard as illustrated in Figure 1. 


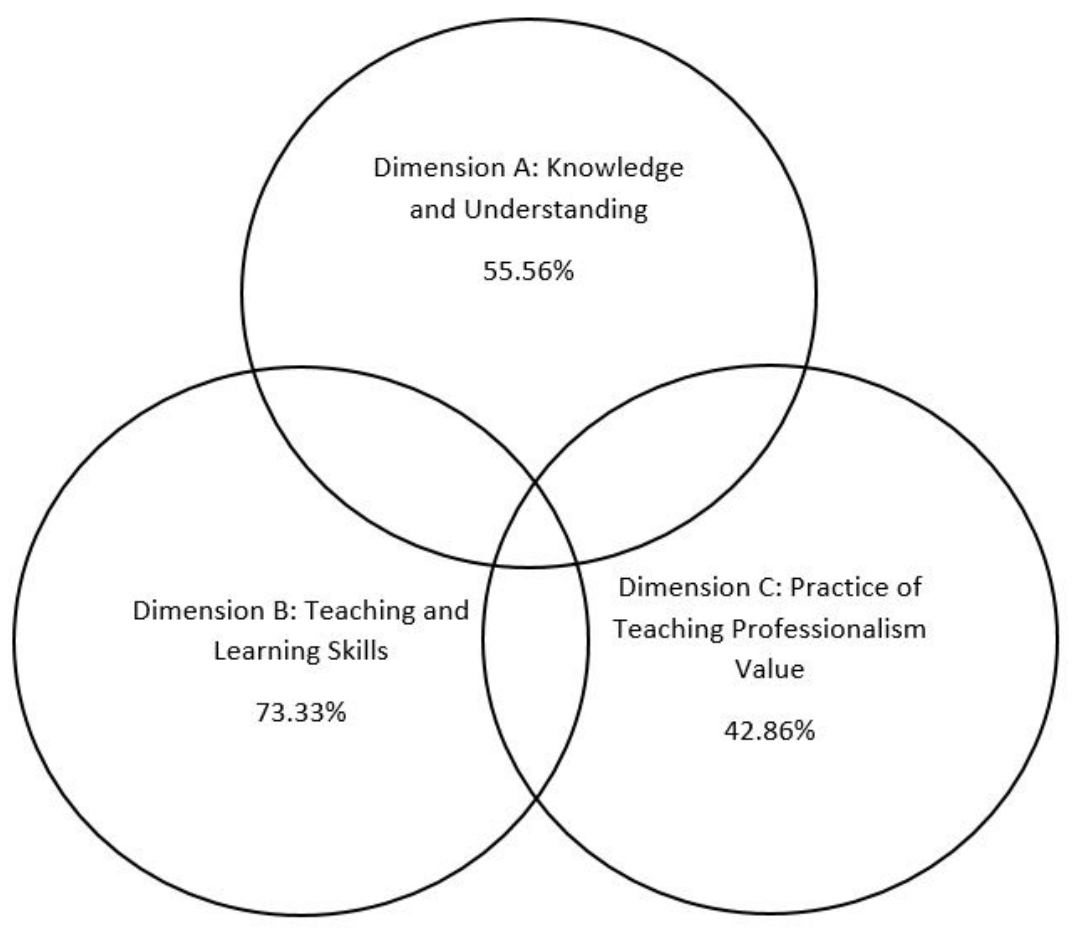

Figure 1. Framework of the Malaysian STEM Teacher's Standard

\section{Discussion}

One of the keys to increase students' academic achievement is to improve the quality of the teacher. According to Hanushek and Pace [32] and Bonney et al. [33], quality teachers can increase students' academic achievement and the overall quality of education. In accordance to this statement, the expert panels provide more emphasis on Dimension B and Dimension A as they believe that only teachers who can effectively deliver the knowledge through various STEM pedagogies and acquire profound knowledge would be able to increase the understanding of the students, therefore enhancing the overall academic achievement of the students. With references to the Shulman's [37] Pedagogical Content Knowledge theory - it is argued that teacher with diverse teaching approaches and deeper content knowledge should be able to implement effective teaching. Findings indicate that although being knowledgeable about subject matter is really important as it allows the teacher to provide better explanation to the students. Nonetheless, the most essential skills to be mastered by STEM teachers are the pedagogical approaches as this encourages teachers to be confident and well prepared in relating STEM classroom learning to outside of classroom experiences.

This study suggests that visionary towards increasing the students' achievement in the national examination causes Dimension $\mathrm{C}$ to be less emphasised by the expert panels. This indicates that the expert panels pay less attention towards the professionalism value among STEM teachers as this aspect was barely emphasised during the teacher training programs. This situation as reported by Anderson and Helms [34] and Snoek [35], might lead to false perceptions about teaching profession being less professional hampering the overall image of this profession.

The importance of teaching professionalism is emphasized by the National Science Teachers Association [36]. According to the National Science Teachers Association [36], science teacher is required to act professionally by providing appropriate learning opportunities to each student, enhancing their knowledge and portraying positive of teaching profession to the community. Apart from the National Science Teacher Association [36], NRC (2006) also emphasizes the need for teachers to practice professional values as professional teachers constantly update their knowledge and skills. The contrasting finding of this study is worth for further investigation to explore the factors leading to undervalue of professionalism among STEM experts.

\section{Conclusions}

The proposed Early Framework of the Malaysia STEM Teacher Standard is built based on the experts' agreement on the characteristics of quality STEM teachers suggested in previous studies and the Malaysia Teacher Standard. 
Both literature and current findings acknowledge teachers' competencies in STEM pedagogy as the most important dimension. However, the findings differ from the existing literature in which the latter views STEM teachers' professionalism as the second most important dimension. Interestingly, the findings relate accordingly to the following level of importance; Dimension B: Teaching and learning skills, Dimension A: Knowledge and Understanding and lastly, Dimension C: Practice of teaching professionalism value. A point to note, this study focuses specifically on developing STEM teacher standard, nevertheless the methodology employed in developing the STEM teacher standard could be replicate by other disciplines to design their own teacher standard. Nonetheless, this early framework is subjected to variations when conducted in different education systems. It is hoped that the proposed Early Framework of the Malaysia STEM Teacher Standard will be able to assist STEM teachers to self-evaluate their competencies as well as serve as a fundamental groundwork for the construction of a responsive and comprehensive teacher training curriculum to improve the quality of STEM teachers.

\section{REFERENCES}

[1] Lee, M. N. School science curriculum reforms in Malaysia: World influences and national context. International Journal of Science Education, Vol.14, No.3, pp. 249-263, 1992.

[2] Kamisah Osman, Lilia Halim \& T.Subahan Mohd Meerah. Pembinaan Instrumen untuk Mengenalpasti Tanggapan Keperluan Semasa Guru-guru Sains di Malaysia. Jurnal Pendidik dan Pendidikan, No.21, pp. 101-113, 2006

[3] Darling-Hammond, L., Flook, L., Cook-Harvey, C. Barron, B., \& Osher, D. Implications for educational practice of the science of learning and development. Applied Developmental Science, pp. 1-44, 2019

[4] Podolsky A, Kini T, Darling-Hammond L, Bishop J. Strategies for attracting and retaining educators: What does the evidence say? education policy analysis archives. Vol. 27, pp.38, 2019.

[5] Mincu ME. Teacher quality and school improvement: what is the role of research? Oxford Review of Education. Vol. 41, no. 2, pp.253-69, 2015.

[6] Margot KC, Kettler T. Teachers' perception of STEM integration and education: A systematic literature review. International Journal of STEM Education. Vol.6, no.1, pp.2, 2019.

[7] Kurup PM, Li X, Powell G, Brown M. Building future primary teachers' capacity in STEM: based on a platform of beliefs, understandings and intentions. International Journal of STEM Education. Vol. 6, no.1, pp.10, 2019.

[8] El Nagdi M, Leammukda F, Roehrig G. Developing identities of STEM teachers at emerging STEM schools.
International journal of STEM education. Vol.5, No.1, pp.36, 2018.

[9] Montgomery, C. and Fernández-Cárdenas, J.M., 2018. Teaching STEM education through dialogue and transformative learning: global significance and local interactions in Mexico and the UK, Vol. 44, no.1, pp.2-13, 2018.

[10] Sulaiman, N. R. Pengajran Sains KBSM. Dewan Bahasa Dan Pustaka: Selangor. 1998.

[11] Khairul Anuar Abdul Muluk. Dasar Pemahaman Konsep Fizik Bagi Pelajar-pelajar Tingkatan 4 di MRSM Jasin Melaka. Tesis Sarjana Pendidikan. Universiti Kebangsaan Malaysia. Bangi. 2003.

[12] Robiah Sidin. Pembudayaan Sains dan Teknologi: Satu Cadangan Piawai. Jurnal Pendidikan UKM, No.28, pp. 47-63, 2003.

[13] Mahmud, S.N.D., Nasri, N.M., Samsudin, M.A. and Halim, L., Science teacher education in Malaysia: challenges and way forward. Asia-Pacific Science Education, Vol.4, no.1, pp.1-12, 2018.

[14] Siew, N.M., Amir, N. \& Chong, C.L. The perceptions of pre-service and in-service teachers regarding a project-based STEM approach to teaching science. SpringerPlus Vol. 4, no. 8, 2015 https://doi.org/10.1186/2193-1801-4-8

[15] Altan EB, Üçüncüoglu I, Öztürk N. Preparation of Out-of-School Learning Environment Based on Science, Technology, Engineering, and Mathematics Education and Investigating Its Effects. Science Education International. Vol. 30, no. 2, pp.138-148, 2019.

[16] Hess, Frederick M. Tear down this wall: The case for a radical overhaul of teacher certification. Educational Horizons Vol. 80, no. 4, pp. 169-183, 2001.

[17] Walsh, K. Teacher Education Reconsidered. Stumbling for Quality. 2001. http://www.abell.org/pubst.htm (15 January 2010)

[18] Zurida Haji Ismail dan Hashim Mohd Yunus. Sikap dan keyakinan guru-guru prasekolah dalam pengajaran sains awal. Prosiding Seminar Kebangsaan Pendidikan Awal dan Pendidikan Khas kanak-kanan, pp. 158-164, 2004.

[19] Fitzgerald, M., Danaia, L, and McKinnon, D.H., Barriers inhibiting inquiry-based science teaching and potential solutions: perceptions of positively inclined early adopters. Research in Science Education Vol. 49, no. 2, pp. 543-566, 2017

[20] Jamil Ahmad. Tinjauan mengenai Kekangan-kekangan dalam Pelaksanaan Sains KBSM di Sekolah-sekolah Menengah di Negeri Kedah Darul Aman. Tesis Sarja Pendidikan. Fakulti Pendidikan. Universiti Kebangsaan Malaysia, 1993.

[21] Madani, R. A. Analysis of Educational Quality, a Goal of Education for All Policy. Higher Education Studies, Vol.9, no.1, pp. 100-109, 2019.

[22] Shernoff DJ, Sinha S, Bressler DM, Ginsburg L. Assessing teacher education and professional development needs for the implementation of integrated approaches to STEM education. International Journal of STEM Education.Vol.4, 
no.1, pp13, 2017.

[23] Korthagen, Fred AJ. In search of the essence of a good teacher: Towards a more holistic approach in teacher education. Teaching and teacher education Vol.20, no.1, pp.77-97, 2004.

[24] No Child Left Behind Act of 2001, Pub. L. No. 107-110, 115 Stat. 1425 (2002)

[25] Kelley TR, Knowles JG. A conceptual framework for integrated STEM education. International Journal of STEM Education. Vol. 3, no. 1, pp.11, 2016.

[26] International Organization for Standardization. Standards Development. 2010. http://www.iso.org/iso/standards_dev elopment/process_and_procedures/drafting_standards.htm

[27] British Standard Institution. Faster, Smarter, Better: Using Standards to Tackle the Recession. 2009. http://www.bsigroup.com/upload/Standards\&Publication/F aster,smarter,betterfinal.pdf

[28] Linstone, Harold A., and Murray Turoff, eds. The delphi method. Reading, MA: Addison-Wesley, 1975.

[29] Green RA. The Delphi technique in educational research. Sage Open. Vol. 4, no. 2, 2014.

[30] Ludwig, Barbara G. "Internationalizing Extension: An exploration of the characteristics evident in a state university Extension system that achieves internationalization." PhD diss., The Ohio State University, 1994.

[31] Hasson F, Keeney S, McKenna H. Research guidelines for the Delphi survey technique. Journal of advanced nursing. Vol. 32, no. 4, pp.1008-1015, 2000.

[32] Hanushek, E. A., \& Pace, R. R. (1995). Who chooses to teach (and why)? Economics of education review, Vol.14, no.2, pp. 101-117, 1995.

[33] Bonney EA, Amoah DF, Micah SA, Ahiamenyo C, Lemaire MB. The Relationship between the Quality of Teachers and Pupils Academic Performance in the STMA Junior High Schools of the Western Region of Ghana. Journal of Education and Practice. Vol. 6, no. 24, pp.139-150, 2015.

[34] Anderson, C. W. \& Helms, C. The Planning and Teaching Intermediate Science Study: Final Report. Research Series No. 147. Michigan State University, East Lansing MI: Institute for Research on Teaching, 2001.

[35] Snoek M. Theories on and concepts of professionalism of teachers and their consequences for the curriculum in teacher education. Hogeschool van Amsterdam, The Netherlands. 2012.

[36] National Science Teachers Association. Standards for Science Teacher Preparation. 2003. http://www.nsta.org/pd fs/NCATE-NSTAStandards2003.pdf (20 Mac 2010)

[37] Shulman, L. S. Those who understand: Knowledge growth in teaching. Educational Researcher, Vol.15, no.2,pp.4-14 